DOI: https://doi.org/10.32836/2521-666X/2020-68-26

УДК 004.738.5:338.46

\author{
Олексенко Ю.О. \\ магістр, \\ Національний університет «Києво-Могилянська академія» \\ Сидоренко О.В. \\ доктор економічних наук, професор, \\ Національний університет «Києво-Могилянська академія» \\ Oleksenko Yuliia, Sydorenko Oksana \\ National University of Kyiv-Mohyla Academy
}

РЕКЛАМНА ДІЯЛЬНІСТЬ ПІДПРИЄМСТВА ТА НАПРЯМИ ЇЇ УДОСКОНАЛЕННЯ

\title{
ADVERTISING ACTIVITY OF THE ENTERPRISE AND DIRECTIVES OF ITS IMPROVEMENT
}

Сьогодні реклама міцно вкоренилася у свідомості споживачів та є невід'ємною складовою частиною діяльності компаній. Саме тому компаніям важливо розуміти, яку роль реклама займає в ефективному просуванні, та навчитися правильно використовувати маркетингові інструменти залежно від виду діяльності. У статті визначено суть та поняття реклами як невід 'ємного елемента комплексу маркетингу на підприємствах. Охарактеризовано роль реклами в ефективному просуванні та надана ї̈ характеристика. Розглянуто основні наявні канали комунікацій та функиї реклами. Визначено принциии, яким повинна відповідати рекламна кампанія. Здійснено аналіз ринку реклами та проведено дослідження щодо сприйняття реклами споживачами. 3'ясовано, які критерії впливають на рімення про здійснення покупки. Охарактеризовано основні тенденції рекламної діяльності підприємств у сфері нерухомості. 3'ясовано головні критерії, яким повинна відповідати реклама у сфері нерухомості. Визначено шляхи та напрями вдосконалення рекламної діяльності та надано рекомендащії щодо покращення рекламної діяльності підприємств у сфері нерухомості.

Ключові слова: реклама, рекламна діяльність, рекламна кампанія, рекламне повідомлення, канал комунікації, сфера нерухомості.

На сегодняшний день реклама прочно укоренилась в сознании потребителей и является неотъемлемой составляющей деятельности компаний. Именно поэтому компаниям важно понимать, какую роль реклама занимает в эффективном продвижении, и научиться правильно использовать маркетинговые инструменты в зависимости от вида деятельности. В статье определена суть и понятие рекламы как неотъемлемого элемента комплекса маркетинга на предприятиях. Охарактеризована роль рекламы в эффективном продвижении и предоставлена ее характеристика. Рассмотрены основные существующие каналь коммуникаций и функиии рекламы. Определены принципы, которым должна соответствовать рекламная кампания. Осуществлен анализ рынка рекламы и проведены исследования восприятия рекламы потребителями. Выяснено, какие критерии влияют на решение о совершении покупки. Охарактеризованы основные тендениии рекламной деятельности предприятий в сфере недвижимости. Определены главные критерии, которым должна соответствовать реклама в сфере недвижимости. Предложены пути и направления совершенствования рекламной деятельности и даны рекомендации по улучшению рекламной деятельности предприятий в сфере недвижимости.

Ключевые слова: реклама, рекламная деятельность, рекламная кампания, рекламное сообщение, канал коммуникащии, сфера недвижимости.

That is commonly excepted fact that advertising is an essential part of everyday life. On the one hand, directly or indirectly, advertising effects a person's daily routine, indicating the way of public life, and sometimes forms his tastes, and preferences, and behavior. On the other hand, advertising has become the need and inevitable part of enterprises regardless of their specialization. Advertising, like any other type of marketing communications, plays an important role in the implementation of marketing and communication strategies of enterprises. Serious and constantly increasing competition forces enterprises of various fields of activity to regularly attract the attention of potential consumers. For more effective results, business needs to constantly stimulate sales, which is one of the main purposes of advertising. Thus, advertising creates the conditions for motivation to buy the product or service that leads to increasing in profitability of the enterprise. Currently, more and more enterprises seek to improve the effectiveness of its activities and use different marketing tools. This creates the relevance of this topic for further research. Recently, the tendency of increasing spending on advertising campaign on the market has been noticed. That is why, it is necessary to understand what an advertising campaign should be like in order to attract a potential consumer and make him buy a product or service. There are many studies in scientific literature dedicated to marketing elements including advertising activities. But for now there is little amount of information about the management of the advertising campaign in the field of real estate business. Lack of knowledge in this sphere proves its importance. The article describes the main theoretical concepts and functions of advertising and principles which must comply with advertising on the legislative level. What is more, the key trends of promotional activities of enterprises in real estate sphere were described. Futhermore, the article examines the features of the advertising communications on a real estate market and its main particular qualities. Also, a survey was conducted on consumer attitudes towards advertising and the potential impact it has on them. Moreover, the question of necessary elements that must be present in advertising campaigns of a real estate enterprise was considerated. On the basis of this study some recommendations for improvement of advertising activity of companies in the real estate sector were formed and, what is more, the list of the most suitable communication channels was given. sphere.

Key words: advertising, advertising activity, advertising campaign, advertising message, communication channel, real estate 
Постановка проблеми. На сучасному етапі розвитку соціально-економічних процесів в Україні швидкого розвитку набувають маркетингові механізми просування на ринку, серед яких одним із ключових є рекламна діяльність. Добре продумана маркетингова стратегія підприємства може радикально вплинути на позиції компанії на ринку та місце, яке вона займає відносно своїх конкурентів. А тому підвищення конкурентноздатності є пріоритетним завданням для підприємств. Компанії, які не використовують рекламну діяльність, виходять із ринку через неспроможність конкурентної боротьби.

Розвиток маркетингової діяльності загалом та рекламної зокрема знаходиться лише на початковому етапі в Україні, а тому потребує подальшого дослідження i створює актуальність для пошуку нових напрямів удосконалення рекламної діяльності підприємств. Наукове дослідження грунтується на робочій гіпотезі про вплив рекламної діяльності підприємства на кількість продажів та довіру до бренду, а в кінцевому підсумку - на збільшення дохідності підприємства.

Рекламна діяльність є дуже динамічною категорією, де постійно додаються нові методи та поняття. Оскільки рекламна діяльність знаходиться лише на етапі розвитку в Україні, то це створює потребу досліджувати нові підходи до ведення рекламної діяльності підприємств. У таких випадках зарубіжний досвід не $є$ адаптованим до сучасного українського ринку. Таким чином, виникає необхідність знаходити нові підходи щодо оптимізації рекламної діяльності та створювати нові методи оцінки ефективності рекламної діяльності підприємства.
Аналіз останніх досліджень та публікацій. Дослідженням рекламної діяльності на підприємстві займалися такі вітчизняні та зарубіжні вчені, як Ч. Сендідж [1], Ф. Джефкінс [2], Ж.Ж Ламбен [3] та інші. Т.В. Ляпіна [4] та У. Уеллс [5] проводили дослідження щодо сутності, принципів рекламної діяльності, а також щодо взаємодії рекламних суб'єктів. Окрім цього, актуальною темою для досліджень була проблема управління рекламною діяльністю на підприємстві, яку у своїх працях висвітлювали Ю.Б. Миронов [6], В. Музикант [7] та інші.

Метою роботи $є$ вивчення сучасних теоретичних основ і методів рекламної роботи в ринковому середовищі і застосування їх у практиці рекламної діяльності підприємства, а також вироблення практичних рекомендацій для удосконалення рекламної діяльності підприємств у сфері нерухомості з метою підвищення споживчого попиту.

Виклад основного матеріалу дослідження. Добре розвинутий інститут рекламної діяльності є запорукою успішного функціонування ринкової економіки як всередині країни, так і заїі межами. Реклама є одним із ключових елементів та рушійною силою розвитку ринку.

Наявність різноманітних та часом взаємозаперечливих визначень поняття «реклама» відображає всю складність цієї категорії та іiї трактування (табл. 1).

Незважаючи на відмінності у формулюваннях, якщо узагальнити, то можна визначити рекламу як процес передачі, поширення або представлення інформації через певний канал комунікації за участю рекламодавця і можливого споживача, який спрямований на переконання споживача купити товар чи послугу. Осо-

Таблиця 1

Підходи до визначення поняття «реклама»

\begin{tabular}{|c|c|}
\hline Визначення & Джерело \\
\hline $\begin{array}{l}\text { Реклама - це неособиста форма комунікації, що здійснюється за допомогою платних засо- } \\
\text { бів поширення інформації з чітко зазначеним джерелом фінансування }\end{array}$ & Ф. Котлер \\
\hline $\begin{array}{l}\text { Реклама - інформація про особу чи товар, розповсюджена в будь-якій формі і в будь-який } \\
\text { спосіб і призначена сформувати або підтримати обізнаність споживачів реклами та їх } \\
\text { інтерес щодо таких особи чи товару }\end{array}$ & $\begin{array}{l}\text { Закон України } \\
\text { «Про рекламу» }\end{array}$ \\
\hline $\begin{array}{l}\text { Реклама - це друковане, рукописне, усне або графічне повідомлення про особу, товар, по- } \\
\text { слуги або громадський рух, що йде від рекламодавця й оплачене ним з метою збільшення } \\
\text { збуту, розширення клієнтури, одержання голосів або публічного схвалення }\end{array}$ & В. Музикант \\
\hline $\begin{array}{l}\text { Реклама - оплачена неперсоналізована комунікація, що здійснюється ідентифікованим } \\
\text { спонсором і використовує засоби масової інформації з метою схилити до чогось аудиторію } \\
\text { чи вплинути на неї }\end{array}$ & У. Уеллс, Дж. Бернет \\
\hline $\begin{array}{l}\text { Реклама є будь-якою формою неособистого представлення і просування ідей, товарів } \\
\text { чи послуг, оплачувану точно встановленим замовником і слугує для залучення уваги } \\
\text { потенційних споживачів до об'єкта рекламування, використовуючи при цьому найбільш } \\
\text { ефективні прийоми і методи з урахуванням конкретної ситуції }\end{array}$ & $\begin{array}{l}\text { За визначенням Американської } \\
\text { Асоціації Маркетингу }\end{array}$ \\
\hline $\begin{array}{l}\text { Реклама - це форма комунікації, яка намагається перевести якості товарів і послуг, а також } \\
\text { ідеї на мову потреб і запитів споживача }\end{array}$ & $\begin{array}{l}\text { Ч. Сендідж, В. Фрайбургер, } \\
\text { А. Ротцолл }\end{array}$ \\
\hline $\begin{array}{l}\text { Реклама - це відгалуження масової комунікації, в руслі якого створюються і поширюються } \\
\text { інформативно-образні, експресивно-сугестивні тексти, адресовані групам людей з метою } \\
\text { спонукати їх до потрібного рекламодавцю вибору і вчинку }\end{array}$ & В. Ученова та Н. Старих \\
\hline $\begin{array}{l}\text { Реклама - це засіб комунікацій, який дозволяє підприємству передати повідомлення по- } \\
\text { тенційним покупцям, прямий контакт з якими не встановлений }\end{array}$ & Жан Жак Ламбен \\
\hline
\end{tabular}

Джерело: узагальнено авторами [1, 3, 8-13] 


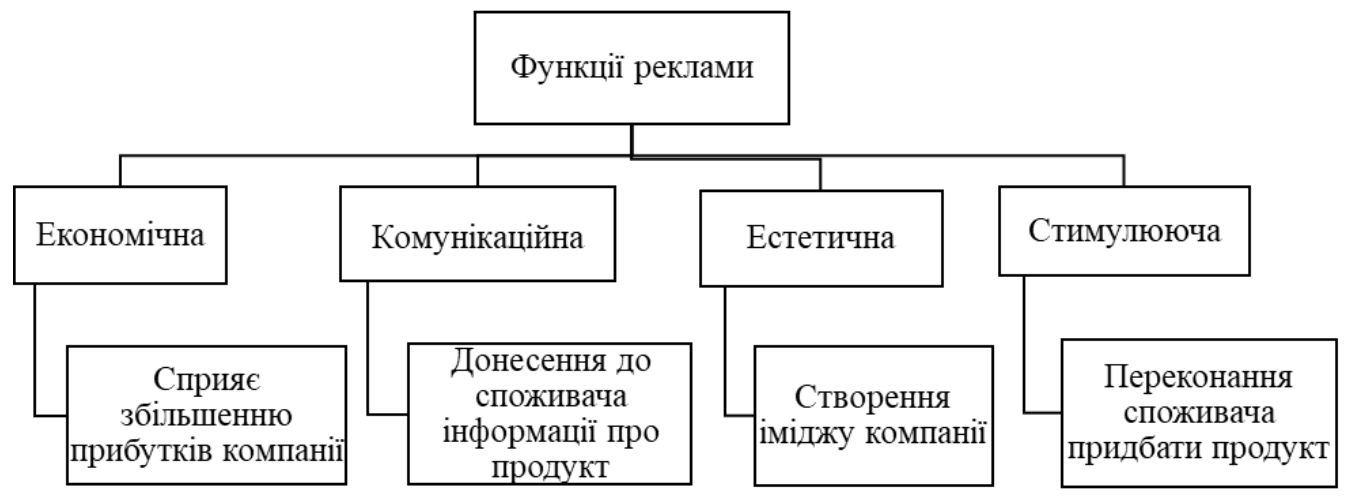

Рис. 1. Основні функції реклами

Джерело: розроблено авторами на основі даних [14]

бливістю реклами є необхідність привертання уваги задля досягнення основної комунікативної мети.

Існує велика кількість трактувань цього поняття, проте всі науковці погоджуються, що рекламна діяльність є основним елементом маркетингової діяльності підприємства і допомагає залучати потенційних споживачів та спонукає їх до покупки товару або послуги.

Незважаючи на те, що реклама є ключовим елементом маркетингової діяльності підприємства, слід пам'ятати, що вона дієва тільки в комплексі з іншими маркетинговими інструментами.

Основними завданнями реклами продукту чи послуги є інформування про їхні переваги, створення інтересу у споживача; створення позитивного іміджу підприємства та прискорення здійснення купівлі, створення попиту. Відповідно, на основі вищевикладеного матеріалу можна виділити такі функції реклами, що наведені на рис. 1:

Згідно із законом України «Про рекламу», до основних принципів реклами належать такі [10]:

- законність, точність, достовірність, використання форм та засобів, які не завдають споживачеві реклами шкоди;

- реклама не повинна підривати довіру суспільства до реклами та повинна відповідати принципам добросовісної конкуренціі;

- реклама не повинна містити інформації або зображень, які порушують етичні, гуманістичні, моральні норми, нехтують правилами пристойності;

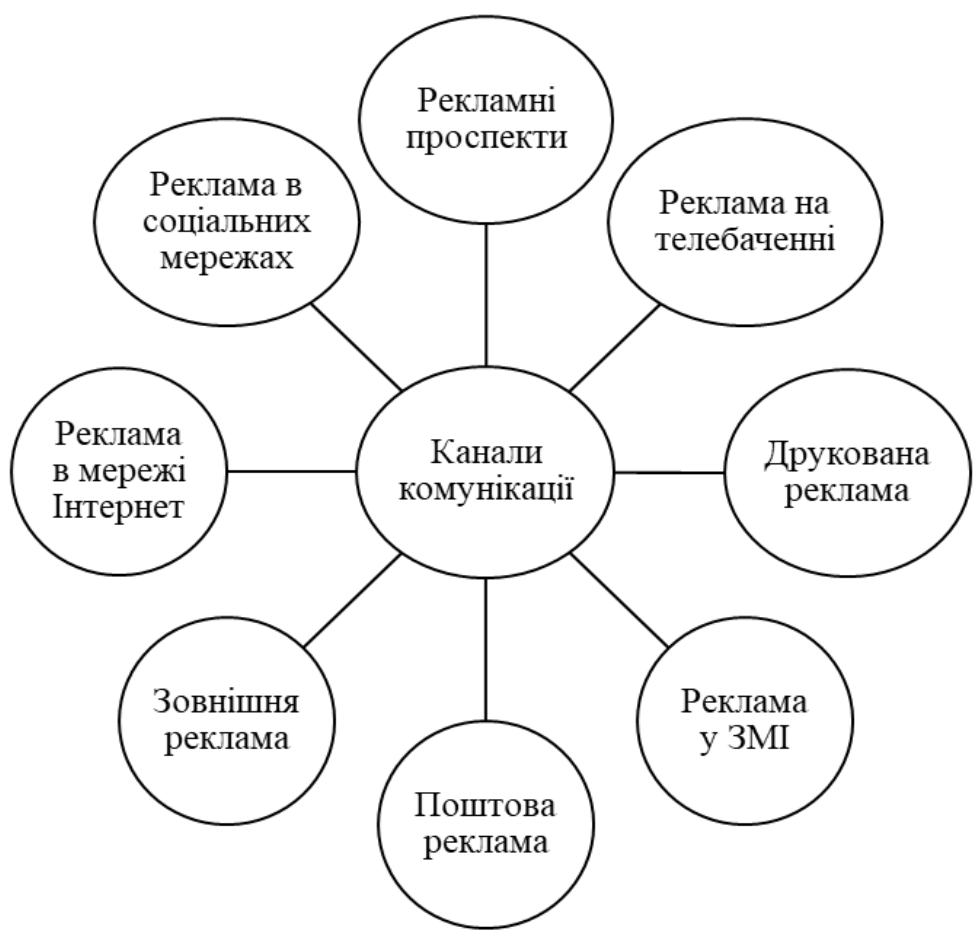

Рис. 2. Найбільш поширені канали комунікацій

Джерело: розроблено авторами на основі даних [15] 
- реклама повинна враховувати особливу чутливість дітей і не завдавати їм шкоди.

Також залежно від типу підприємства та його продукту можна використовувати різні канали комунікації (рис. 2):

Задля більш глибокого аналізу цієї тематики нами було проведено опитування. Воно було розділене на два основні блоки запитань: щодо ставлення до рекламної діяльності компаній загалом та щодо рекламної діяльності підприємств зі сфери нерухомості зокрема. В опитуванні взяло участь 116 осіб, серед яких 66,4\% жінки і 33,6\% чоловіки. Більшу частину займають респонденти віком від 18-25 років (73,3\%). Друга за розміром група осіб - віком 35 років і старше $(21,6 \%)$. Найменшими за кількістю йдуть групи до 18 років $(2,6 \%)$ та від 25-35 (2,6\%).

Надалі було проаналізовано ставлення респондентів до реклами та рівень довіри до рекламних кампаній у повсякденному житті. На запитання про те, які відчуття виникають при слові «реклама» більшість $(60,3 \%)$ респондентів відповіли «нейтральні» (рис. 3).

Проте на запитання «Чи довіряєте Ви рекламі?» більшість (78\%) відповіли «ні» (рис. 4). Це свідчить про те, що навіть якщо споживач і не дратується від по-

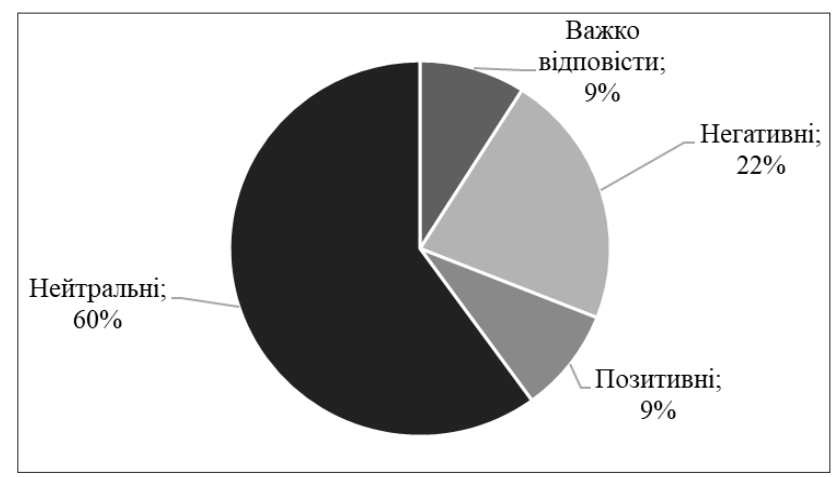

Рис. 3. Ставлення респондентів до реклами Джерело: розроблено авторами на основі проведеного опитування

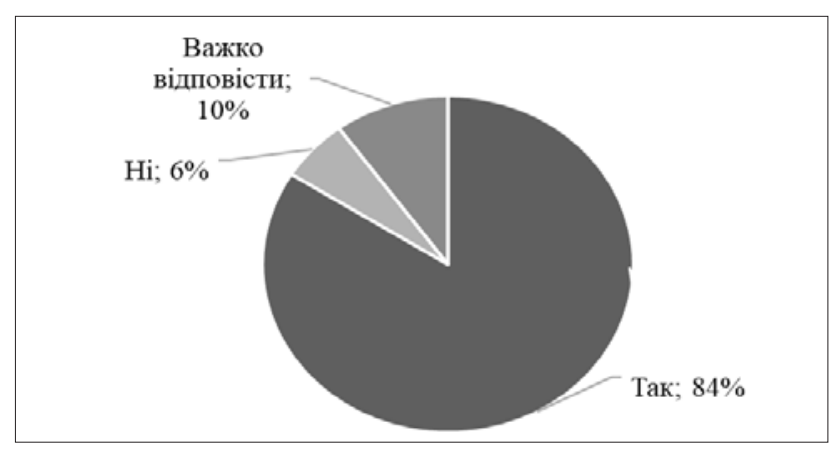

Рис. 5. Розподіл відповідей респондентів на запитання «Чи допомагас Вам реклама дізнаватися про нові продукти та товари?»

Джерело: розроблено авторами на основі проведеного опитування баченої реклами, то він ії̈ не сприймає серйозно, оскільки рівень довіри до рекламних повідомлень невисокий.

Понад це, респонденти відповіли, що все ж таки реклама допомагає дізнаватися про нові продукти $(84,5 \%)$ та іноді навіть викликає бажання дізнатися про продукт додаткову інформацію $(69,8 \%$ ) (рис. 5,6$)$.

Таким чином, можна зробити висновок, що в інформативній рекламній кампанії реклама є важливим джерелом інформації для споживачів і може викликати в них бажання дізнаватися про товар чи послугу.

Щодо рушійних факторів під час виборі товару чи послуги, то одним із найголовніших можна назвати власні потреби чи необхідність у товарі (рис. 7).

Серед усіх перелічених факторів останню позицію займає реклама товарів, а тому можна зробити висновок, що лише реклама найменше впливає на рішення про покупку.

Проте іноді реклама може підштовхувати споживачів до цього. Це відбувається підсвідомо, оскільки під час здійснення покупки товар, рекламу якого споживачі вже бачили раніше, здається їм знайомим. Підтвердження отримали із запитання «Наскільки реклама впливає на Ваш вибір продукту/товару/ послуги?», де 83,6\% респондентів відповіли «іноді впливає» (рис. 8). А тому можна говорити про хоч i

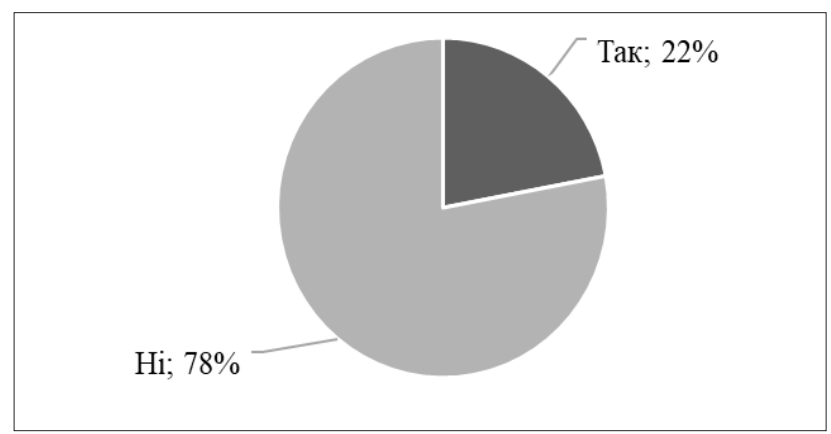

Рис. 4. Розподіл респондентів за довірою до реклами

Джерело: розроблено авторами на основі проведеного опитування

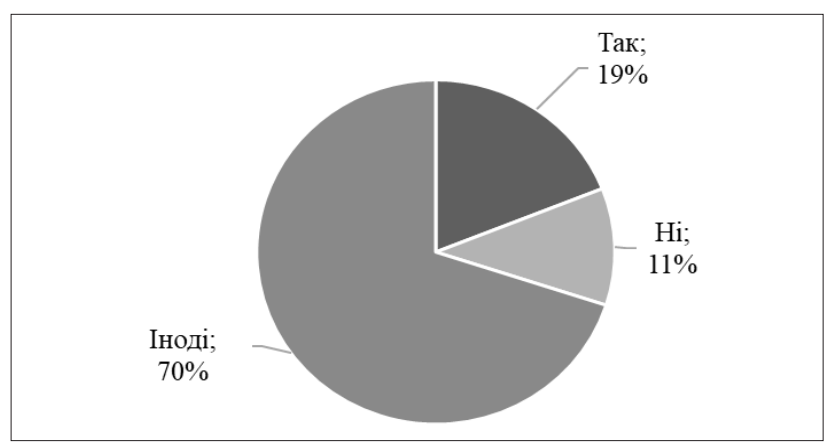

Рис. 6. Розподіл відповідей респондентів на запитання «Чи викликає у Вас реклама бажання дізнатися про продукт додаткову інформацію?»

Джерело: розроблено авторами на основі проведеного опитування 


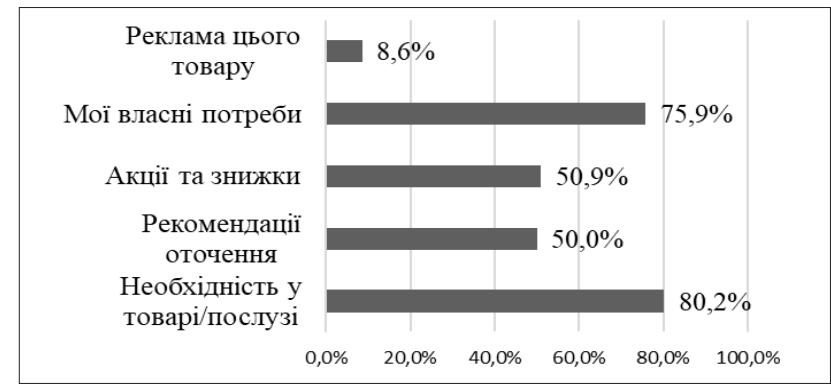

Рис. 7. Рушійні фактори здійснення покупки

Джерело: розроблено авторами на основі проведеного опитування

не визначальну, проте велику роль реклами і їі вплив на бажання зробити покупку.

Дослідженням було також проаналізовано найбільш популярні канали комунікації серед споживачів (рис. 9). Як результат, частіше всього рекламу бачать в Інтернеті, на телебаченні та у соціальних мережах. Найменше з рекламою знайомляться в метро та у місяцях продажу.

Якщо оцінювати канали комунікації, які найбільше дратують споживачів, то це знову ж таки будуть Інтернет, телебачення та розсилки на пошту (рис. 10). Тоді як ненав'язливою вважають рекламу у місцях продажу, зовнішню та в метро.

3 вищенаведеного можна стверджувати: Інтернет-простір та телебачення перевантажені рекламою, тому частіше за інші канали комунікації викликають негативні емоції у споживачів. Це призводить до того, що реклама може мати навіть негативний ефект. Вибір каналу комунікації є надзвичайно важливим елементом рекламної кампанії. Таким чином, компаніям необхідно правильно вибирати рекламні платформи, щоб представити свій товар/послугу якомога краще та не викликати у споживача негативних емоцій.

Кожній компанії важливо розуміти бажання та інтереси свого споживача, щоби правильно створити комунікаційне повідомлення. Зрозуміло, що вони повинні керуватися критеріями якості реклами. Для уявлення про пріоритети споживачів, а саме що бажають отримувати від рекламних повідомлень та якою хочуть бачити рекламу, в межах опитування було поставлено

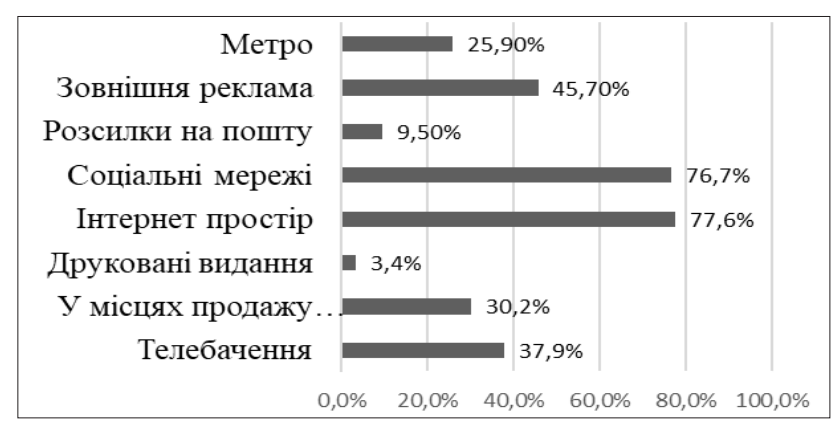

Рис. 9. Місця, де респонденти найчастіше бачать рекламу

Джерело: розроблено авторами на основі проведеного опитування

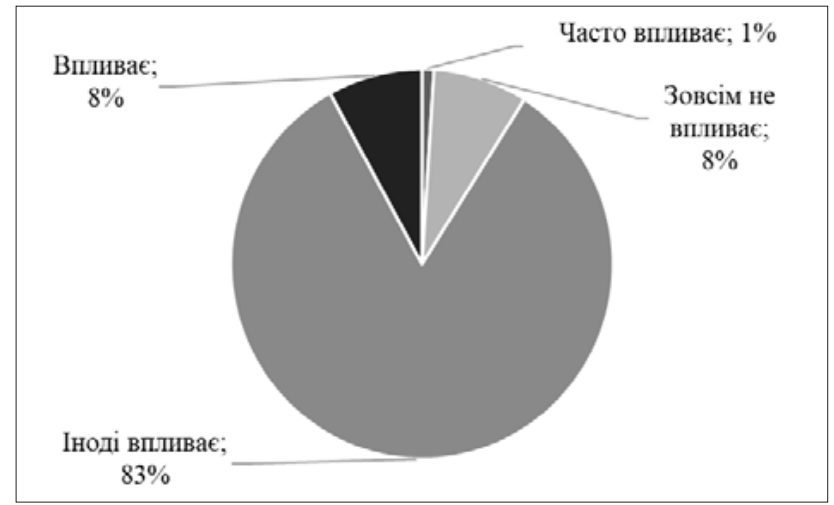

Рис. 8. Вплив реклами на вибір
продукту/послуги респондентами

Джерело: розроблено авторами на основі проведеного опитування

запитання: «На Вашу думку, які якості важливі для реклами, щоб вона викликала у Вас інтерес та довіру?». Результати наведені у табл. 2.

Відтак було виділено найважливіші критерії реклами: зрозумілість, корисність та відповідність дійсності. Отже, рекламне повідомлення повинно бути чітко сформульоване, доносити зрозумілий посил до споживача та не прикрашати продукт, а відображати його справжні характеристики. Також досить важливими $є$ оригінальність, візуальна естетичність, лаконічність, наявність опису продукту та інформації про ціну. Якщо об'єднати обидві групи критеріїв, то рекламне повідомлення повинно мати такий вигляд: оригінальне та естетично оформлене, стисле та зрозуміле повідомлення, що описує продукт та надає про нього додаткову правдиву інформацію.

Щодо факторів, що є найменш важливими, то до них можна віднести розмір рекламного повідомлення та наявність у рекламі людей. Це не означає, що цими факторами можна нехтувати, проте потрібно розуміти, що вони не мають критично важливого значення під час сприйняття рекламного повідомлення.

Другий блок стосувався проблем реклами у сфері нерухомості. Для цього сегменту бізнесу критично необхідною є наявність такої реклами, що охоплює най-

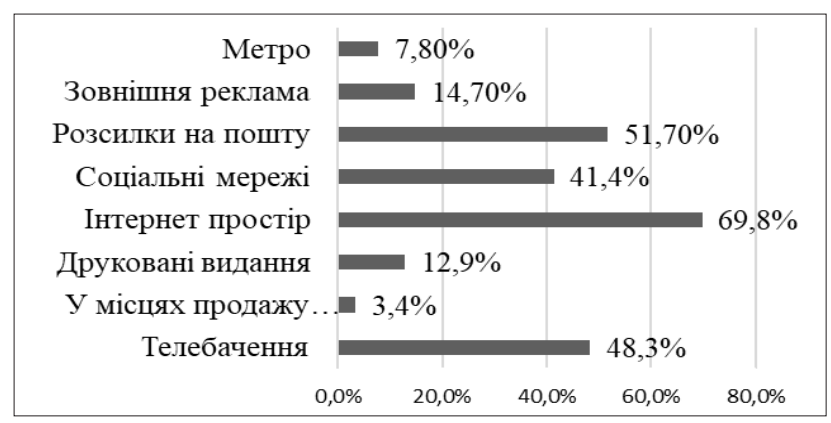

Рис. 10. Місця реклами, що найбільше дратують респондентів

Джерело: розроблено авторами на основі проведеного опитування 
Важливість критеріїв реклами для споживачів

\begin{tabular}{|l|c|}
\hline \multicolumn{1}{|c|}{ Критерій } & Оцінка важливості \\
\hline Реклама відповідає дійсності & 5 \\
\hline Зрозумілість & 5 \\
\hline Корисність & 4 \\
\hline Оригінальність & 4 \\
\hline Візуально гарна реклама & 4 \\
\hline Лаконічність реклами & 4 \\
\hline Наявність детального опису продукту/послуги & 4 \\
\hline Наявність інформації про ціну продукту/послуги & 3 \\
\hline Джерело реклами & 3 \\
\hline Місце розташування реклами & 3 \\
\hline Реклама у форматі відео & 3 \\
\hline Реклама у форматі фото з текстом & 3 \\
\hline Бренд, що рекламується & 3 \\
\hline Розважальний характер & 2 \\
\hline Мова & \\
\hline Розмір реклами (наприклад, великий борд чи маленька листівка) & 1 \\
\hline Наявність людей у рекламі & 1 \\
\hline
\end{tabular}

Джерело: розроблено авторами на основі проведеного опитування

Таблиця 3

Чинники що мають / не мають вплив на рішення покупців

\begin{tabular}{|c|c|}
\hline Впливають & Не впливають \\
\hline Наявний власний сайт & У компанії немає сторінки у Facebook \\
\hline Немає реклами (раніше ніколи не чули про компанію) & У компанії немає сторінки Instagram \\
\hline
\end{tabular}

Джерело: розроблено авторами на основі проведеного опитування

більшу цільову аудиторію за мінімальних витрат (адже чим дешевше коштуватиме реклама, що залучить найбільше клієнтів, тим більше прибутку отримає компанія). Результати опитування підтверджують важливість цієї тези. На запитання «Чи вплине на Ваше рішення про придбання квартири те, що Ви вже колись чули про назву житлового комплексу або компанії-забудовника?» майже абсолютна більшість $(86,2 \%)$ відповіли «так» (рис. 11).

Наявність добре продуманої маркетингової стратегії необхідна для успішного функціонування компанії у сфері нерухомості, адже це збільшує довіру до забудовника і прискорює реалізацію нерухомості.

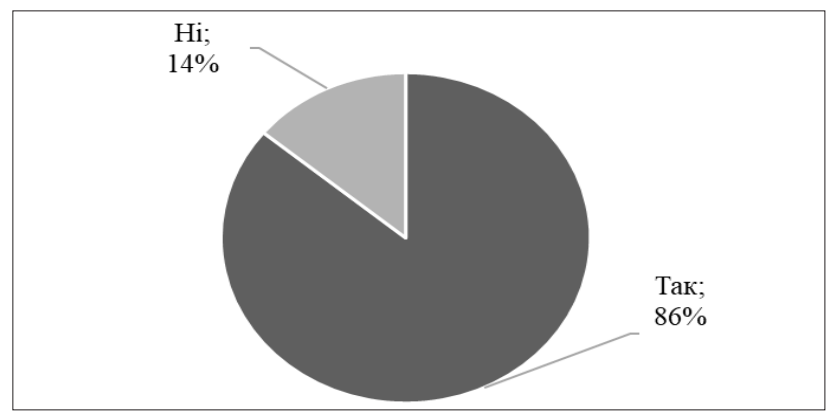

Рис. 11. Вплив реклами компанії на рішення про придбання квартири респондентами

Джерело: розроблено авторами на основі проведеного опитування
Також на рішення споживачів про придбання квартири, згідно з опитуванням, мають вплив і інші фактори, зокрема (табл. 3).

Отже, як бачимо, наявність сторінок у соціальних мережах не $\epsilon$ важливим для компанії у сфері нерухомості критерієм. Натомість акцентуємо увагу, що наявність реклами та власного сайту мають важливе значення під час ухвалення рішення про придбання квартири та викликають більшу довіру серед споживачів, а отже, і забезпечують більшу прибутковість для компанії.

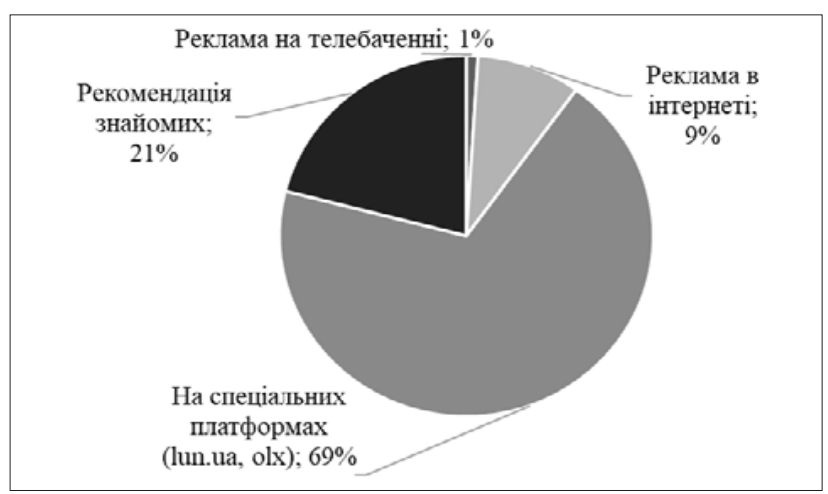

Рис. 12. Платформи, які респонденти будуть використовувати для пошуку квартири

Джерело: розроблено авторами на основі проведеного опитування 


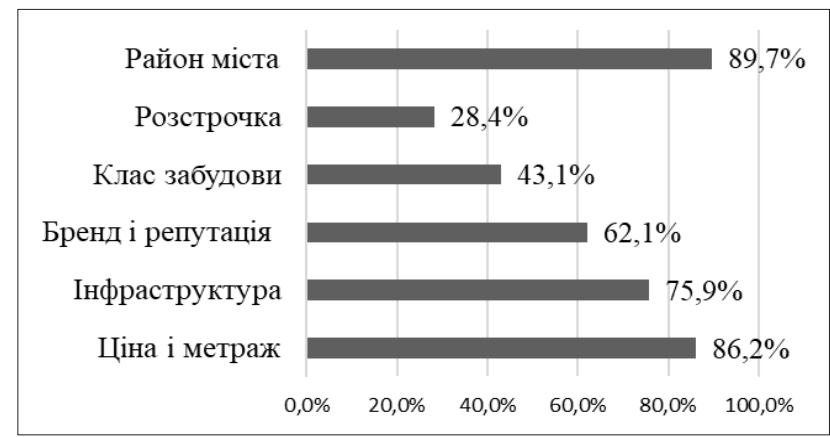

Рис. 13. Необхідні елементи рекламної кампанії у сфері нерухомості

Джерело: розроблено авторами на основі проведеного опитування

Для пошуку квартири більшість респондентів (69\%) будуть користуватися спеціальними платформами на зразок olx, lun.ua (рис. 12). Тому важливо, щоб компанія використовувала рекламу на цих сайтах та розміщувала свої пропозиції там також. Понад це, як виявилося, реклама на телебаченні взагалі не є підставою для подальшого пошуку квартири чи зацікавлення пропозицією. Це також потрібно враховувати і, зважаючи опитування, проводити рекламні кампанії в Інтернеті, де це буде дешевше й ефективніше.

За допомогою запитання «На Вашу думку, яку інформацію повинна містити в собі ідеальна реклама квартири?» було встановлено найважливіші критерії для споживачів. Таким чином, реклама компаній у сфері нерухомості, щоб привернути увагу споживача і задовольнити його інтерес, має містити такі дані (рис. 13).

3 наведеної діаграми очевидно, що трьома основними пунктами є зазначення району, в якому розташована будівля, ціни і площі квартири, а також наявна навколо інфраструктура. Це той мінімум інформації, що має містити рекламне повідомлення.
На основі проведеного дослідження можна розробити рекомендації для удосконалення рекламних кампаній у сфері нерухомості, серед яких:

- рекламне повідомлення повинно бути зрозумілим, лаконічним та інформативним;

- рекламне повідомлення має бути візуально естетичне, оригінальне, у відео- або фотоформаті;

- розміщувати рекламу варто у соціальних мережах, а також на спеціалізованих платформах;

- не варто розміщувати рекламу на телебаченні (оскільки це дорого та малоефективно) та використовувати зовнішню рекламу;

- правильна реклама може збільшити довіру до компанії та, як наслідок, прискорити реалізацію квартир;

- важливо розвивати власний сайт компанії та постійно оновлювати його, оскільки він є важливим джерелом інформації для потенційних покупців;

- потрібно привертати увагу споживачів акціями та знижками, оскільки саме наявність таких пропозицій може спонукати до покупки.

Висновки. Отже, в результаті цього дослідження стало зрозумілим, що для реклами у сфері нерухомості найбільш придатні більш сучасні канали комунікацій, такі як реклама в мережі Interent та у соціальних мережах, а також на спеціальних платформах (lun.ua, olx). Це зумовлено більшою залученістю споживачів (оскільки нині все більше цільової аудиторії зосереджено саме в мережі Internet). Крім того, отримані результати вказують і на те, що споживачі мають чіткі вимоги до рекламних повідомлень, а тому компанії у сфері нерухомості повинні враховувати ці критерії під час створення рекламної кампанії. Для цього необхідно постійно проводити аналіз ринку та цільової аудиторії, оскільки сучасні тенденції мають властивість дуже швидко змінюватися. Це доводить, що ринок нерухомості поступово відходить від традиційних рекламних інструментів та починає розвиватися у сучасних, більш близьких форматах для споживача.

\section{Список літератури:}

1. Сендідж Ч. Реклама: теорія і практика: монографія. Москва : Сирин, 2001. 236 с.

2. Джефкінс Ф. Реклама : навч. посіб. Москва : Юнити-Дана, 2008. 543 с.

3. Ламбен Ж.-Ж. Менеджмент, ориентированный на рынок : навч. посіб. Санкт-Петербург : Питер, 2007.800 с.

4. Ляпіна Т.В. Бізнес і комунікації або школа сучасної реклами : монографія. Київ : Альтерпрес, 2000.336 с.

5. Бернет Д., Моріарті С., Уеллс У. Реклама : принципи і практика : навч. посіб. Київ : Логос, 1999. 290 с.

6. Миронов Ю.Б. Основи рекламної діяльності : навч. посіб. Дрогобич : Посвіт, 2007, 108 с.

7. Музикант В.Л. Теорія та практика сучасної реклами : навч. посіб. Миколаїв : Євразійський регіон, 2008. $376 \mathrm{c}$.

8. Котлер Ф. Основи маркетингу : монографія. Москва : Вильямс, 2007. 656 с.

9. Владимирська Г.О., Владимирський П.О. Реклама : навч. посіб. Київ : Кондор, 2009. 334 с.

10. Про рекламу : Закон України від 11 липня 2003 р. № 1121-IV. Дата оновлення: 01.02.2020. URL : https://zakon.rada.gov.ua/laws/show/270/96-вр. (дата звернення: 02.03.2020)

11. Рекламная деятельность : учебник. / Панкратов Ф.Г та ін. Москва : Дашков и Кㅇ, 2002. 364 с.

12. Ромат Є.В. Реклама: навч. посіб. Київ : Студцентр, 1999. 480 с.

13. Ученова В.В, Старих Н.В. История рекламы : навч. посіб. Санкт-Петербург : Питер, 2002. 304. с.

14. Компанієць T.I. Вплив реклами на просування споживчих товарів в умовах сучасного ринку. Економіка та управління підприємствами. 2014. № 3 (27). С. 63-67.

15. Ковшова І. О., Михайлюк А. М. Організація рекламної діяльності на підприємстві. Економіка. Менеджмент. Бізнес. 2015. № 1. - С. 46-53. 


\section{. References:}

1. Sendidzh Ch. (2001) Reklama Teoriia I Praktyka [Advertising: theory and practice]. Moskva : Sirin.

2. Dzhefkins F. (2008) Reklama [Advertising]. Moskva : Yunyty-Dana.

3. Lamben Zh.-Zh. (2007) Menedzhment, oriyentirovannyy na rynok [Market Oriented Management]. Sankt-Peterburg : Piter.

4. Liapina T.V. (2000) Biznes I Komunikatsii Abo Shkola Suchasnoi Reklamy [Business and communications or modern advertising school]. Kyiv : Alterprec.

5. Bernet D. Moriarti S. Uells U. (1999) Reklama Pryntsypy I Praktyka [Advertising: principles and practice]. Kyiv : Lohos.

6. Myronov Yu.B. (2007) Osnovy Reklamnoi Diialnosti [Basics of advertising]. Drohobych : Posvit.

7. Muzykant V.L. (2008) Teoriia Ta Praktyka Suchasnoi Reklamy [Theory and practice of modern advertising]. Mykolaiv : Yevraziiskyi Rehion.

8. Kotler F. (2007) Osnovy Marketynhu [Basics of marketing]. Moskva : Vil'yams.

9. Vladymyrska H.O. Vladymyrskyi P.O. (2009) Reklama [Advertising]. Kyiv : Kondor.

10. On advertising: Law of Ukraine, No. 1121-IV of 11 Juny 2003, as amended. Available at: https://zakon.rada.gov.ua/ laws/show/270/96-вр. (accessed 1 February 2020).

11. Pankratov F.G., Bazhenov YU.K., Seregina T.K., SHakhurin V.G. (2002) Reklamnaya deyatel'nost' [Advertising activity]. Moskva : Dashkov i Ko.

12. Romat Ye.V. (1999) Reklama [Advertising]. Kyiv : Studtsentr.

13. Uchenova V.V, Starikh N.V. (2002) Istoriya reklamy [The history of advertising]. Sankt-Peterburg : Piter.

14. Kompaniiets T.I. (2014) Vplyv Reklamy Na Prosuvannia Spozhyvchykh Tovariv V Umovakh Suchasnoho Rynku [The impact of advertising on the promotion of consumer goods in today's market]. Ekonomika Ta Upravlinnia Pidpryiemstvamy, no 3 (27), pp. 63-67.

15. Kovshova I. O. Mykhailiuk A. M. (2015) Orhanizatsiia Reklamnoi Diialnosti Na Pidpryiemstvi [Organization of advertising activities of the enterprise]. Ekonomika. Menedzhment. Biznes, no 1, pp. 46-53. 